\title{
Anatomical aspects of the forearm muscles of Myrmecophaga tridactyla
}

\section{Aspectos anatômicos dos músculos do antebraço de Myrmecophaga tridactyla}

\author{
Daniel Barbosa da Silva ${ }^{1 *} \oplus$, Paulo Cesar Moreira ${ }^{1} \odot$, Viviane Souza Cruz¹ ${ }^{\oplus}$, \\ Eduarda Pereira Santana² ${ }^{\oplus}$, Alberto Corrêa Mendonça ${ }^{\circledR}$, Júlio Roquete Cardoso ${ }^{\circledR}$
}

\begin{abstract}
The giant anteater is one of the species classified as vulnerable to extinction. Burning and being run over are among important causes in the decrease of individuals of this species and a better knowledge of the anatomy of these animals can contribute to the treatment of injured animals and their restoration to the environment. Thus, the objective of this work was to describe aspects of the anatomy of the muscles of the forearm of $M$. tridactyla. For this purpose, six adult specimens were used, three females and three males. The corpses were fixed with a $10 \%$ formaldehyde solution and preserved in vats containing the same solution. The thoracic limbs were dissected by routine dissection techniques. The forearm muscles of $M$. tridactyla were: brachioradialis; radial carpal extensor; common finger extensor; lateral finger extensor, ulnar carpal extensor; finger extensor I and II; long abductor of finger I; supinator, radial carpal flexor; ulnar flexor of the carpus, superficial flexor of the fingers, deep flexor of the fingers, pronator teres and square pronator, which were innervated by the radial, ulnar and median nerves. These muscles give a large volume to the forearm, are robust and have highly developed tendons, especially those involved with the flexion of the carpus, digits and elbow, actions that are fundamental to your defense habits and search for food.
\end{abstract}

KEYWORDS: thoracic limb, muscles, myrmecophagidae, xenartra.

RESUMO: O tamanduá-bandeira é uma das espécies classificadas em condição vulnerável à extinção. Queimadas e atropelamentos estão entre causas importantes na diminuição de indivíduos desta espécie e um melhor conhecimento da anatomia destes animais pode contribuir para o tratamento de animais feridos e seu reestabelecimento ao meio ambiente. Assim, oobjetivo deste estudo foi descrever os aspectos da anatomia do antebraço do $M$. tridactyla. Para tanto, foram utilizados seis exemplares adultos, sendo três fêmeas e três machos. Os cadáveres foram fixados com solução aquosa de aldeído fórmico 10\% e preservados em cubas contendo a mesma solução. Os membros torácicos foram dissecados pelas técnicas rotineiras de dissecação para evidenciação dos músculos, vasos e nervos da região. Os músculos do antebraço do $M$. tridactyla foram: braquiorradial; extensor radial do carpo; extensor comum dos dedos; extensor lateral dos dedos, extensor ulnar do carpo; extensor dos dedos I e II; abdutor longo do dedo I; supinador, flexor radial do carpo; flexor ulnar do carpo, flexor superficial dos dedos, flexor profundo dos dedos, pronador redondo e pronador quadrado. Estes músculos foram inervados pelos nervos ulnar e mediano. Juntos estes músculos conferem um grande volume ao antebraço, e suas características apontam para uma poderosa capacidade de exercer a flexão do carpo e dos dígitos, e ainda contribuir com os músculos do braço para a flexão do cotovelo, ações estas fundamentais aos seus hábitos de defesa e busca por alimento.

PALAVRAS-CHAVE: membro torácico, músculos, myrmecophagidae, xenartra

\section{INTRODUCTION}

The Myrmecophaga tridactyla, popularly known as the giant anteater, it is a mammal of the family Myrmecophagidae, suborder Vermilingua, order Pilosa and super order Xenarthra (MIRANDA; COSTA, 2006; GAUDIN et al., 2018). He, together with the young anteater (Tamandua tetradactyla) and the dwarf anteater (Cyclopes didactylus), they are part of the same gender and have similar anatomo-physiological and behavioral traits (MIRANDA; COSTA, 2006). It is a species considered vulnerable at national level (MIRANDA et al., 2015).

Although the giant anteater is one of the Latin American species best known to the public around the world, there is relatively little knowledge about its behavior, ecology and 
physical abilities (YOUNG et al., 2003). Although studies on the forearm musculature have already been carried out in other members of the xenarth order, such as the giant anteater T. tedradactyla (TAYLOR, 1978), sloth Bradypus variegatus (DINIZ et al., 2018) and armadillo Dasypus novemcinctus (OLSON et al., 2015), these aspects are still unprecedented in the $M$. tridactyla. The thoracic members, in addition to the natural importance in locomotion, are also fundamental in the defense behavior and in the habit of obtaining food in this species, and as a result, many morphological adaptations can be observed in these appendices (SOUSA et al., 2014).

The ecological importance of this species and its condition of vulnerability to extinction, coupled with the small amount of information about its anatomy, point to the need for further studies to meet the veterinary medical interest, especially in the area of surgery.

Thus, the objective of this study was to describe aspects of the anatomy of the musculature of the giant anteater's fore$\operatorname{arm}(M$. tridactyla).

\section{MATERIALS AND METHODS}

Twelve forearms of six adult anteater (M. tridactyla) specimens, three females and three males were dissected in this study. The carcasses were donated by IBAMA-GO and the research project approved by the ethics committee on the use of animals at UFG (CEUA-UFG 018/2014). The cadavers were thawed at room temperature for a period of approximately 48 hours, then washed and fixed by intramuscular and intracavitary injections of $10 \%$ aqueous formaldehyde solution and preserved in vats containing the same solution.

For dissection of the muscular, vascular and nervous structures of the forearm, the skin and the forearm fasciae were removed. The muscles were isolated and their proximal and distal fixations (origin and insertion), morphology and topography described. The action of the muscles was proposed from the appreciation of their morphology, topography, their points of attachment to the skeleton and the direction of the muscle fibers in relation to the joints and the axis involved in each movement.

The dissected anatomical pieces were photographed using a Canon EOS 80D camera.

\section{RESULTS}

In general, the $M$. tridactyla forearm stands out visually for its robustness. Its diameter is notably larger than that of the arm, due to its developed bones and bony reliefs and musculature. All muscles are bulky, but the muscles involved in flexing the carpus and digits stand out and those that contribute to the flexion of the elbow. In this group, the brachioradial muscle and deep digital flexor stand out.

Notable bone reliefs serve as fixation for this differentiated musculature, such as large epicondyles and humeral supracondylar ridges, olecranon, extensor processes and phalanx flexors.
Of the five digits of the hand of $M$. tridactyla, the third is the most developed and has the largest claw, and it is the same as the majority and the most developed tendons, both extensors and flexors. The second digit is also developed, and has a relatively large claw, while the first and fourth digits have smaller claws. The fifth digit is not visible, with its phalanges covered by the palm pad.

The following muscles in the forearm were identified: brachioradialis; radial carpal extensor; common finger extensor; lateral finger extensor, finger extensor I and II; ulnar extensor carpus; long abductor of finger I; supinator, radial carpal flexor; ulnar flexor of the carpus, deep superficial flexors of the fingers, pronator teres and pronator teres. (Figures 1,2 and 3).

The brachioradial (M.) muscle (Figure 1A) is located on the cranial surface of the forearm and extends over the medial surface of the forearm. In its deep face, there is a relationship with the carpal radial extensor, pronator teres and carpal radial flexor muscles. It originates on the cranial surface of the middle portion of the humeral shaft, and insertion occurs at the distal end of the radius and in the retinaculum of the extensors.
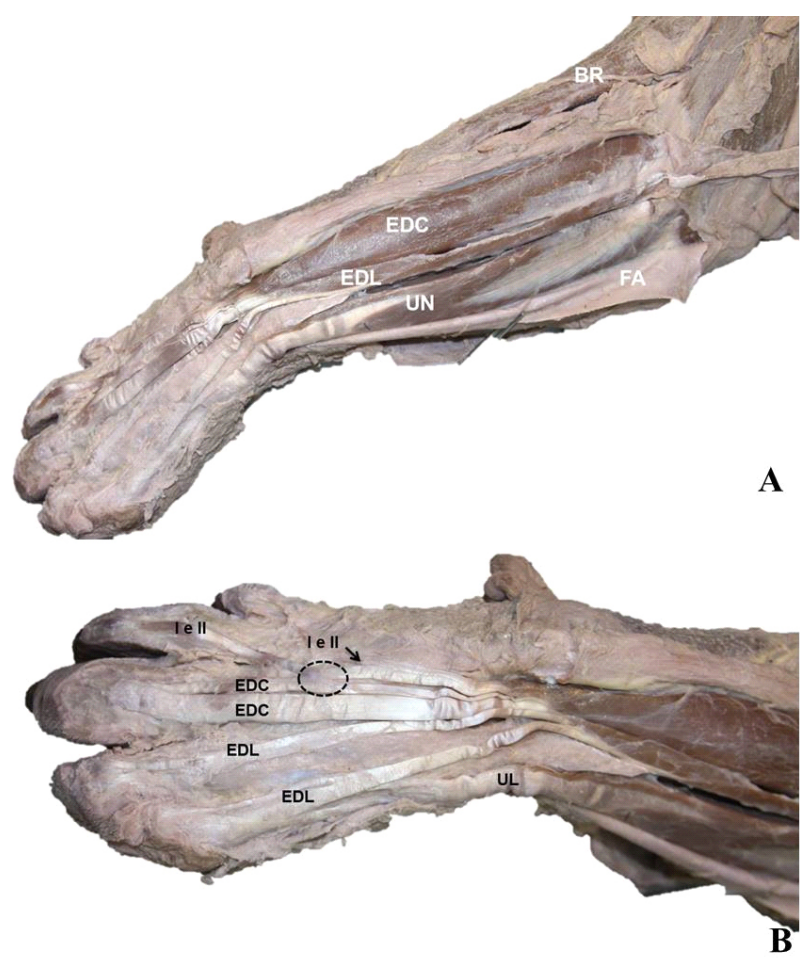

Source: author's collection.

Figure 1. Craniolateral view of the left forearm of $M$. tridactyla showing the muscular bellies $(A)$ and in detail their insertions on the dorsal surface of the hand (B). BR- M. brachioradial, EDC- M. common digital extensor, EDL- Digital lateral extensor, I and II- M. finger extensor I and II, UN- lateral ulnar M. (carpal ulnar extensor), FA- Fascia of the forearm, dashed area - joint between tendons of the extensor muscles of fingers I and II and common digital extensor. 
The medial band is inserted in the flexor retinaculum and in the caudal portion of the forearm fascia.

The carpal radial extensor $M$. has a conical shape, is in superficial contact with the brachioradial M. and deeply with the brachial muscles, superficial digital extensor and supinator. The origin is in the lateral epicondylar crest and in the lateral part of the acromial portion of M. deltoide. Its insertion tendon slides under the tendon of the long abductor $\mathrm{M}$. of finger I, crosses the aponeurosis of the distal insertion of the M. brachioradialis and inserts on the dorsal surface of the distal third of the metacarpal bone III.

The common digital extensor (Figure 1) is found on the craniolateral face of the forearm between the M. radial carpal extensor and the lateral digital extensor. It originates in the lateral epicondyle and epicondylar crest. Distally to the dorsal surface of the carpus, the insertion tendon is divided into two branches: lateral and medial. The lateral, which is the thickest, is inserted in the distal phalanx of the third digit; and the medial branch is inserted in the middle phalanx of the same digit (Figure 1B).

The extensor M. of fingers I and II originates in the middle third of the ulna. Its belly is located deeply to the common digital extensor and lateral digital extensor muscles. Distally from the carpus its insertion tendon divides into two branches. The medial branch inserts on the dorsal face of the distal phalanx of the digit I and the lateral branch, more robust, merges for a short extension with the tendon of the common extensor M. of the fingers and follows individually to insert itself on the dorsal face of the phalanx. distal of the second digit (Figure 1B).

The M. lateral extensor of the fingers (lateral digital extensor) (Figure 1) is located between the common extensor muscles of the fingers and the ulnar extensor of the carpus and originates in the lateral epicondyle of the humerus. Its medial branch is inserted in the distal phalanx of the fourth finger and its lateral branch is inserted in the distal end of the fifth metacarpal and in the distal phalanx of the fifth finger. As a result of the fusion between branches of the tendons of the extensors of the finger I and II and common of the fingers, both act in the extension of the second and third fingers, although they do not fix directly in both digits simultaneously.

The lateral ulnar M. (extensor carpi ulnaris) (Figure 1) is found on the lateral aspect of the forearm between the lateral digital extensor muscles cranially and anechoicly and flexor digitorum caudally. The origin is in the lateral epicondyle. Its insertion tendon crosses the dorsolateral surface of the carpus and splits in two. The medial tendon fuses with the tendon of the lateral digital extensor muscle. The lateral tendon inserts on the distal surface of the fifth metacarpal and the tendon of the lateral digital extensor muscle.

The long abductor muscle of the finger I (oblique carpal extensor) is a long and developed muscle and is found deep in the belly of the common digital extensor, lateral digital extensor and ulnar carpal extensor muscles. It originates on the lateral surface of the proximal third of the ulna and on the caudal surface of the proximal third of the radius. The insertion tendon superficially crosses the tendon of the carpal radial extensor to insert itself in the epiphysis of the first metacarpal.

The supinator muscle is located craniolateral to the radius, deep to the common digital extensor and radial carpal extensor
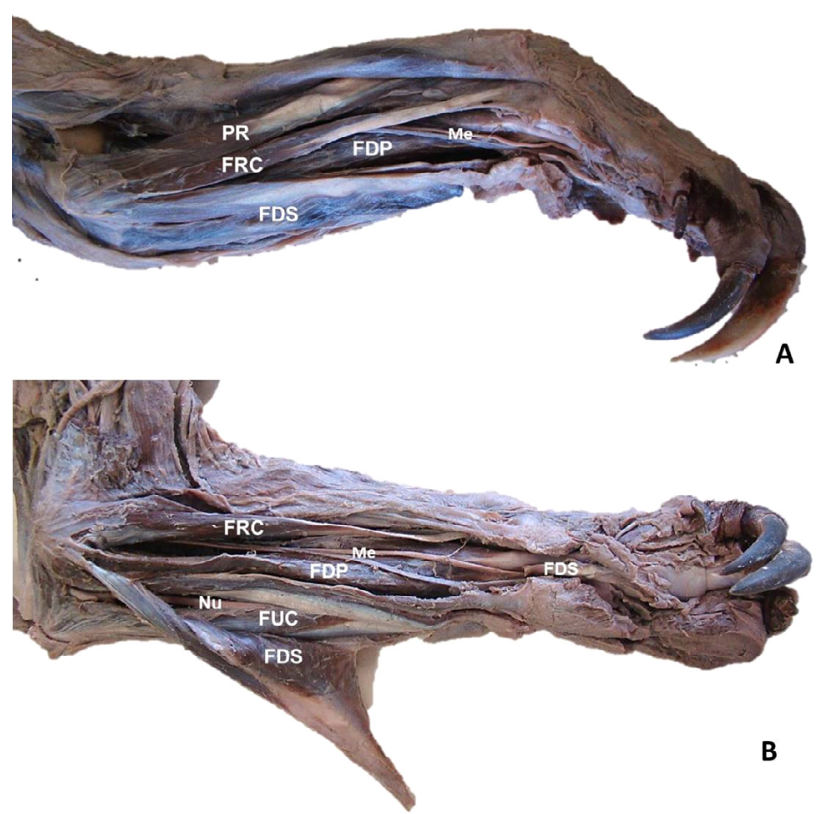

Source: author's collection.

Figure 2. Medial (A) and caudomedial view of the left forearm of M. tridactyla (B). PR- M. pronator teres, FRC- M. radial carpal flexor, FDS- M. superficial digital flexor, FDP- M. deep digital flexor, FUC- M. ulnar flexor carpi, Me- N. median, Nu - N ulnar.

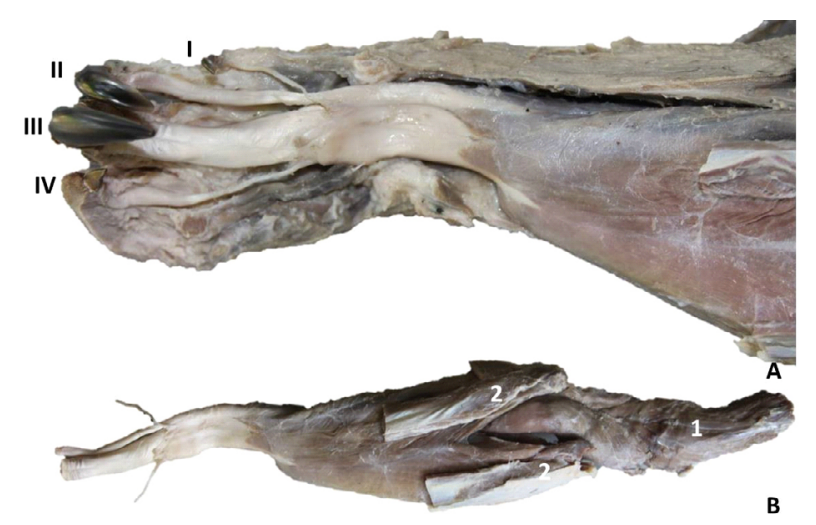

Source: author's collection.

Figure 3. Palmar view showing insertion of $M$. deep digital flexor of M. tridactyla in the right hand $(A)$ and the same muscle removed $(B)$. I to IV - digits, 1 - humeral head portion of the deep digital flexor that extends proximally along the arm, 2 proximal stumps of the sectioned superficial digital flexor. 
muscles. It originates in the lateral epicondyle of the humerus and insertion in the proximal two thirds of the cranial surface of the radius.

The carpal radial M. flexor is located between the M. pronator teres cranially and the superficial flexor of the fingers caudally (Figure 2). It originates in the medial epicondyle and is inserted through a long tendon, which crosses the median vasculonervous bundle and follows the palmar surface of the carpus to fixate at the base of the third metacarpal.

The flexor carpi ulnaris muscle is partly covered by the superficial digital flexor muscle and is deeply related to the deep flexor muscle of the fingers and the ulnar nerve (Figura 2B). It has a humeral head originating from the medial epicondyle of the humerus and an ulnar head originating from the olecranon. These two parts form a strong muscular blade that is inserted in the accessory bone of the carpus and in the retinaculum of the flexors.

The superficial digital flexor muscle is located on the caudomedial surface of the forearm, deeply to the forearm fascia (Figura 2). Fully covers the deep flexor muscles of the fingers and the flexor carpi ulnaris. The proximal portion contains two heads, one ulnar, originating in the tuberosity of the olecranon and the other humeral, originating in the medial epicondyle of the humerus. The insertion occurs through a long tendon that crosses the flexor retinaculum, advances in the distal direction between the tendon of the deep flexor muscle of the fingers and the palmar fascia, to fix itself in the vigorous digital annular ligament of the third digit.

The deep flexor muscle of the fingers is formed by three heads: the humeral head is the most robust, and its muscular belly extends over the entire caudal surface of the humerus and radius (Figure 3B). It originates in the entire caudal surface of the humerus, from the neck to the medial epicondyle; the ulnar head originates from the tuberosity of the olecranon and ulna body and the radial head originates from the entire caudal surface of the radius. These three heads form, at the height of the carpus, a strong tendon that crosses the carpal tunnel. Upon reaching the metacarpal, it is subdivided into four branches that are inserted in the distal phalanges of the first to the fourth digits (Figure 3A).

The pronator teres muscle (Figure $2 \mathrm{~A}$ ) is positioned deeply to the radial extensor and brachioradial muscles and superficially to the deep digital flexor muscle and the median vasculonervous bundle. Its origin occurs in the medial epicondyle together with the radial flexor carpi muscle caudally. Insertion occurs at the distal cranial border of the radius.

The pronator square muscle presents itself as a blade located between the deep side of the deep flexor muscle of the fingers and the caudal face of the radius and ulna. Its fibers present an oblique direction, with fixation on the ulna, proximally and on the radius, distally. Its fibers originate in the ulna and insert in the radius, occluding the interosseous space of the forearm in all its extension, being more robust distally.

The N. ulnar (Figure 2B) crosses the caudal face of the radioumeral joint and at the height of the forearm it emits branches to the ulnar head of the superficial flexor of the fingers, M. ulnar flexor of the carpus and to the ulnar and humeral heads of the M. of the deep flexor of the fingers. It follows distally in contact with the deep side of the latter and divides into superficial and deep branches when crossing the palmar face of the carpus.

The median vasculonervous bundle (Figure 2) deeply crosses the radial flexor carpi and pronator teres muscles to which it emits branches and distally innervates the square pronator M., the humeral heads of the superficial and deep digital flexor muscles and the radial flexor head deep digital.

\section{DISCUSSION}

M. brachiorradial is well developed and was present in all animals studied, a characteristic expected in this species, given the role of this muscle in flexing the elbow joint and the relationship of this movement with the animal's habit. Among domestic animals it is present only in cats and, eventually, in dogs (KONIG; LIEBICH, 2011; SCHALLER, 1999). Among xenarths, it is also described in Tamandua tedradactyla (TAYLOR, 1978), where it has two heads: deep and superficial; and in the sloth Bradypus variegatus (DINIZ et al., 2018), but it was not reported in the armadillo Dasypus novemcinctus (OLSON et al., 2015).

The main origin of $\mathrm{M}$. radial carpal extensor in the Myrmecophaga tridactyla occurred in the lateral epicondylar crest as in the other xenarthras (DINIZ et al., 2018; OLSON et al., 2015; TAYLOR, 1978). However, exclusive insertion in metacarpal III, differs from that described in sloths Bradypus variegatus, where its fixation is in the distal portion of the carpus (DINIZ et al., 2018), and the armadillo Dasypus novemcinctus, whose insertion occurs in the third and fourth metacarpians (OLSON et al., 2015).

The M. extensor of the finger I and II observed in the present study is not reported in domestic animals or in the literature consulted for wild animals. It contributes to the extension of the respective digits and presents a certain joint action with the common finger extensor $M$. because its tendon presents a connection point with it.

Although the tendon of the common finger extensor in the Myrmecophaga tridactyla divided into two branches, both are fixed in the middle and distal phalanges of the third digit, differing from that observed in Dasypus novemcinctus, where insertion occurs in the fourth and fifth digits (OLSON et al., 2015) and carnivores, where it ends in a long tendon of insertion in the distal phalanx extensor process of each functional digit, that is, it has four branches (KONIG; LIEBICH, 2011). The absence of these branches for the first and second digits is compensated by the presence of the extensor muscle of fingers I and II, exclusive to this species. The IV finger extension is in charge of the robust lateral digital extensor.

The origin and disposition of the M. ulnar extensor of the Myrmecophaga tridactyla is similar to that described in the literature (SCHALLER, 1999), however, its insertion 
differs from that observed in these species, given that its insertion tendon divides into two branches, the lateral one being inserted in the fifth metacarpal, as in carnivores (KONIG; LIEBICH, 2011), while medial and still part of the lateral, they are inserted in the tendon of the lateral digital extensor M., giving additional strength to digits IV and V.

The M. pronator round of the $M$. tridactyla has a typical position and origin, but it differs from the standard of carnivores (KONIG; LIEBICH, 2011) due to its more distal insertion on the radio, as also occurs in the sloth (DINIZ et al., 2018). This characteristic not only increases the leverage of the muscle in pronation of the forearm, but also adds strength in the elbow flexion, acting as a synergist of the M. braquiorradial (Diniz et al., 2018). The pronator M. square is similar to that of the dog (KONIG; LIEBICH, 2011), occupying the entire interosseous space of the forearm, different from that described in sloths Bradypus variegatus, whose similarity refers to that of humans (DINIZ et al., 2018).

The radial carpal M. flexor is related to the deep digital M. flexor, but does not fuse with it as described in armadillos Dasypus novemcinctus (OLSON et al., 2015). The M. radial flexor of the carpus of the M. tridactyla inserts at the proximal end of the metacarpal bone III, which differs from what occurs in the sloth Bradypus variegatus, whose insertion takes place in the first metacarpal (DINIZ et al., 2018).

M. flexor carpi ulnaris of the Myrmecophaga tridactyla has an ulnar head and an humeral head with origins in the tuberosity of the olecranon and the medial epicondyle of the humerus, respectively, as in the monkey Cebus apella (AVERSI-FERREIRA et al., 2006) and in domestic animals (SCHALLER, 1999). In the armadillo Dasypus novemcinctus (OLSON, 2015), however, a humeral head was not observed, and its origin in the ulna extends from the olecranon to the surroundings of the styloid process. At the

Myrmecophaga tridactyla, the muscle is inserted in the accessory bone of the carpus and in the flexor retinaculum, different from what happens in the sloth Bradypus variegatus, where its insertion occurs in the third metacarpal (DINIZ et al., 2018).

The superficial digital flexor M. of the Myrmecophaga tridactyla, it has an ulnar head and a radial head, coinciding with that described in Tamandua tetradactyla (TAYLOR, 1978) and in the monkey Cebus apella (AVERSI-FERREIRA et al., 2006). On the other hand, in quati Nasua nasua (SANTOS et al., 2010), in the armadillo Dasypus novemcinctus (OLSON, 2015) and in domestic animals (SHALLER, 1999), it has a single head. Its distal fixation in the finger III digital annular ligament differs quati Nasua nasua, whose insertion occurs in the proximal phalanges of fingers I to IV (SANTOS et al., 2010); carnivores, where it is fixed in the middle phalanges of the fingers II to IV (SCHALLER, 1999) and the armadillo (Dasypus novemcinctus), where insertion takes place in the distal phalanx of finger II and middle finger III e IV (OLSON, 2015). In the sloth Bradypus variegatus, the superficial and deep digital flexor muscles are presented as a single muscle and at the end of their muscular belly these muscles divide, giving rise to the tendon of the deep digital flexor muscle and two other tendons for the superficial digital flexor (DINIZ et al., 2018).

This peculiar insertion of the superficial digital M. Flexor into the M. tridactyla exclusively in the annular ligament of the digit III results that all the flexing action of the digits I, II and IV is the responsibility of the deep digital M. Flexor, and that, interestingly, the finger $\mathrm{V}$ does not undergo an active flexion in this species. The extension occurs because it receives the lateral branch of the tendon of the lateral extensor of the fingers. As this digit has no claw and its bones are not projected in a typical digit, but inserted in the region of the digital cushion, there is therefore no applicability in individually flexing the cushion region simultaneously to the main fingers in the process of destruction of termite mounds and rotten trunks.

The M. Tridactyla deep digital flexor is peculiar, not only because of its volume, but also because it presents great differences in the anatomical pattern of mammals in relation to the origin and asymmetry of the branches of the insertion tendon. The humeral head of this muscle extends very proximally, to the neck of the humerus, which differs from the pattern of domestic animals (KONIG; LIEBICH, 2011; SCHALLER, 1999) and from the other members of the xenarth order (DINIZ et al., 2018; OLSON et al., 2015; TAYLOR, 1978). This wide proximal extension of the humeral head in this species can strengthen the flexor action of the muscle, especially when the elbow flexes, because with this movement, muscle pull would occur, increasing the force imposed on the third digit. Its insertion occurs in the distal phalanges of digits I to IV, and there is also a marked asymmetry between its branches, with the branch for digit III being markedly more developed, differing from domestic carnivores, where it acts proportionally on all digits (KONIG; LIEBICH, 2011).

Due to the anatomical musculoskeletal peculiarities of the forearm of $M$. tridactyla, the accesses proposed here to the radio and ulna differ from the techniques applied to dogs (POZZI; LEWIS, 2009) and cats (SCHMIERER; POZZI, 2017), so that the extrapolation of these Techniques for the clinical-surgical of this species may not be the best choice in reducing fractures in these bones.

\section{CONCLUSION}

The forearm muscles of $\mathrm{M}$. tridactyla are robust, especially those involved with flexion. Among the specializations involved with these actions are the presence of the developed M. brachioradialis, the deep digital flexor with a very proximal atypical origin and concentrated insertion in the third digit, developed superficial digital flexor and with insertion also in the third digit. Together, these characteristics are directly associated with the powerful flexion capacity of the distal joints of the thoracic limb, especially the third digit. 


\section{REFERENCES}

ALEXANDRE AVERSI-FERREIRA, T. et al. Estudo anatômico dos músculos flexores superficiais do antebraço no macaco Cebus apella. Bioscience Journal, v. 22, n. 1, p. 139-144, Jul, 2006.

DINIZ, J. A. R. A. et al. Descrição anatômica dos músculos do membro torácico da preguiça-comum (Bradypus variegatus). Acta Scientiae Veterinariae, v. 46, p. 1-10, 2018.

FERRIGNO, C. R. A. et al. Treatment of radius, ulna and humerus fractures with the aid of a bone morphogenetic protein in a giant anteater (Myrmecophaga tridactyla). Veterinary and Comparative Orthopaedics and Traumatology, v. 16, n. 3, p. 196-200, 2003.

GAUDIN, T. J.; HICKS, P.; DI BLANCO, Y.; Myrmecophaga tridactyla (Pilosa: Myrmecophagidae). Mammalian Species, v. 50, n. 956, p. $1-13,2018$.

KONIG, H. E.; LIEBICH, H. G. Anatomia dos animais domésticos - livro texto. 4ed. Porto Alegre: Artmed, 2011, 788p.

MIRANDA, F.; COSTA, A. M. Xenarthra (tamanduá, tatu, preguiça). In: CUBAS, Z. S.; SILVA, J. C. R; CATÃO-DIAS, J. L. Tratado de animais selvagens: medicina veterinária. São Paulo: Roca, 2006. p. 402- 414.

MIRANDA, F.R.; CHIARELLO, A. G.; RÖHE, F.; BRAGA, F.G.; MOURÃO, G.M.; MIRANDA, G.H.B.; SILVA, K.F.M.; FARIA-CORRÊA, M.A.; VAZ, S.M. \& BELENTANI, S.C.S. 2015. Avaliação do Risco de Extinção de Myrmecophaga tridactyla Linnaeus, 1758 no Brasil. Processo de avaliação do risco de extinção da fauna brasileira. ICMBio. Disponível em: <http://www4.icmbio.gov.br/portal/ faunabrasileira/estado-de-conservacao/7127-mamiferos- myrmecophaga-tridactyla-tamandua-bandeira> Acesso em: 08 abr 2020

OLSON, R. A. et al. Functional morphology of the forelimb of the nine-banded armadillo (Dasypus novemcinctus): Comparative Perspectives on the Myology of Dasypodidae. Journal of Mammalian Evolution, v.23, n.1, p 49-69, 2015.

POZZI, A.; LEWIS, D. Surgical approaches for minimally invasive plate osteosynthesis in dogs. Vet Comp Orthop Traumatol., v. 22, n. 4, p. 316-20, 2009.

SANTOS, A. C. et al. Morfologia dos músculos do ombro, braço e antebraço do quati (Nasua nasua linnaeus, 1758). Biotemas, v. 23, n.3, p. $167-173,2010$.

SCHALLER, 0 . Nomenclatura anatômica veterinária ilustrada. São Paulo: Manole, 1999. 614p .

SCHMIERER, P. A.; POZZI, A. Guidelines for surgical approaches for minimally invasive plate osteosynthesis in cats. Vet Comp Orthop Traumatol., v. 30, n. 4, p. 272-278, 2017.

SOUZA, P.R. et al. Gross anatomy of the brachial plexus in the giant Anteater (Myrmecophaga tridactyla). Anat Histol Embryol, v.43, n.5, p.341-345, 2014.

TAYLOR, B. K. The anatomy of the forelimb in the anteater (tamandua) and its functional implications. Journal of Morphology, v.157, p. 347-367, Set, 1978.

YOUNG, R. J.; C. M. COELHO; D. R. WIELOCH. A note on the climbing abilities of giant anteaters, Myrmecophaga tridactyla (Xenarthra, Myrmecophagidae). Bol. Mus. Biol. Mello Leitão, v. 15, p. 41-46, Jun, 2003. 